\title{
WORKING CAPITAL MANAGEMENT AND PERFORMANCE OF SIX DEPOSIT MONEY BANKS IN NIGERIA
}

\author{
Ochei Ailemen \\ Ikpefan $^{1}$ \\ Godswill Osagie \\ Osuma $^{2+}$ \\ Tersoo Ahire ${ }^{3}$ \\ Grace Evbuomwan ${ }^{4}$ \\ Bayo Oyero Kazeem ${ }^{5}$ \\ Peace Chimezie $^{6}$
}

\author{
${ }^{1,2,3,6}$ Department of Banking and Finance, Covenant University, Ota, Nigeria. \\ sEmail: godswill.osuma@.covenantuniversity.edu.ng \\ ${ }^{~}$ Department of Economics Augustine University, Lagos State, Nigeria. \\ ${ }^{5}$ Department of Banking and Finance Osun State University, Osogbo, \\ Nigeria.
}

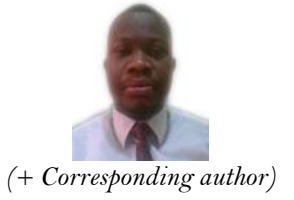

\section{Article History \\ Received: 15 September 2020 Revised: 17 March 2021 \\ Accepted: 21 April 2021 \\ Published: 19 May 2021}

\section{Keywords}

Working capital Financial performance

Return on asset

Liquidity ratio

Capital adequacy.

JEL Classification: G21; G32.

\begin{abstract}
Central to any financial institution's success is working capital management because mismanagement (WCM) can lead to its demise. This research examines the management of working capital in deposit money banks (DMBs) in Nigeria. This study evaluated the impact of liquidity on banks' performance to analyze how their competitiveness influences capital adequacy and assessed the correlation between loans and advances and deposit money banks' profitability. The study utilized a regression analysis, in which panel data was used based on data retrieved from the banks' financial statements from 2010 to 2017 . The findings showed that the primary reason banks hold highly liquid assets is to guard against a rise in demand or unforeseen circumstances. Another reason is to finance working capital operations based on the theory of liquid assets. Therefore, based on the findings it is recommended that direct policies are implemented to ensure that high-volume cash transactions are dramatically reduced.
\end{abstract}

Contribution/Originality: This study contributes to the existing literature by investigating working capital management and the performance of deposit money banks with the use of a pooled regression for an extended period from 2010 through 2017.

\section{INTRODUCTION}

There is a need for the careful use of a bank's resources in a new, dynamic market setting, which includes emphasis put on the management of working capital. With a particular end target, effective working capital management is needed to use opportunities and limit threats. As a very significant component of an organization's assets, we have working capital that turns out to be every company's lifeblood. A business will thrive without income but will remain in continuity, yet it cannot survive when it lacks working capital (Leeson, 2017). Working capital management is a critical factor influencing profit returns of companies worldwide and prioritizes the financial sector, particularly banks. It is widely recognized that corporate organizations' sustainability is primarily based on how they can effectively manage their working capital. Not only can inadequate working capital management affect a bank's profitability, but it is also the lead cause of a bank's instability which could lead to a bank run thus leaving it in poor condition financially. Nonetheless, the unavailability of suitable methods in 
managing working capital could adversely impact practices (Oluwatoyin, 2017). Also, bank undercapitalization can create liquidity issues when very little on-the-ground money is available to satisfy consumer demands, such as withdrawals of funds as needed. Studies also have shown that an opposite relationship between profitability and liquidity exists. Therefore, bank and finance managers must seek a workable equilibrium or tradeoff between these two factors, however, it may not succeed in the long run if a bank is not concerned with earnings. On the contrary, a bank could face insolvency or liquidation by caring less about liquidity and risk. It is necessary for companies to maintain adequate working capital because inadequate working capital could impact the operations of the business adversely. Simultaneously, too much working capital can limit a company's profit-earning capacity (Adagye, 2015). Working capital management may be an essential aspect of corporate finance since its liquidity and profit margins are impacted.

Past studies undertaken by scholars, such as Oluwakayode (2017) and Olabamiji \& Michael (2018), have shown that several deposit money banks have entered deep financial distress. This has been demonstrated by poor scores resulting from inadequate treasury management procedures, poor credit management, and banks' distress. All of these boil down to the main issue of control of working capital; the extremes at either end will make or break a bank. Inadequate working capital and surplus working capital are both severe situations. The consequence, relative to its peers in other nations of the western world, is the underperformance of the Nigerian banking sector. A bank's success depends on its capacity to successfully handle the risks of liquidity and profitability that firms face in the management of working capital, according to Umoren \& Udo (2015). Working capital management is essential for determining the efficiency of a bank.

By fulfilling deposit withdrawal requests, a bank must satisfy its financial commitments to clients. Notably, it has to invest its funds appropriately in valuable assets. Other commitments include meeting the demands for investors' credit and optimizing shareholder value by efficiently managing funds allocated to working capital. If it is unable to satisfy all of the above financial commitments, neglecting working capital activities will slow down its growth rate and undermine public trust. In 2008, the Central Bank of Nigeria (CBN) provided some banks with bailout funds because of their inability to fulfill their clients' financial obligations and because of their high volume of non-performing transactions (loans) (Osuma, Ailemen, Osabohien, Chisom, \& Pascal, 2018).

From the twenty-four (24) deposit money banks in Nigeria, ten (10) of them were deemed distressed and doubtful by the Central Bank of Nigeria as of 2009. The reasons were related to liquidity issues, capital inadequacy and lack of proper risk management procedures (Umoren \& Udo, 2015). A study conducted on the dissolved Skye Bank, claimed that the key causes of its dismal results were capital insufficiency and illiquidity. These contributed to the bank's inefficient working capital operations, which led to its inability to fulfill obligations when they were due and ultimately had a significant impact on its performance and outcome. From the background of this study, it is pertinent to research the reason for the banking sector's recurring issues and provide plausible solutions to the issues identified. Table 1 shows the research questions and hypotheses of the study.

Table 1. Research questions translating to research hypotheses.

\begin{tabular}{l|l}
\hline Research Question & Research Hypothesis (stated in null form) \\
\hline $\begin{array}{l}\text { How would liquidity affect a DMB's management of } \\
\text { working capital? }\end{array}$ & $\begin{array}{l}\text { Liquidity has no significant effect on working capital } \\
\text { management. }\end{array}$ \\
\hline $\begin{array}{l}\text { How does capital adequacy affect a DMB's } \\
\text { productivity? }\end{array}$ & $\begin{array}{l}\text { There is no significant relationship between capital } \\
\text { adequacy and productivity. }\end{array}$ \\
\hline $\begin{array}{l}\text { How does the level of loans and advances affect a } \\
\text { bank's profitability? }\end{array}$ & $\begin{array}{l}\text { The profitability of deposit money banks (DMBs) is } \\
\text { not significantly affected by loans and advances. }\end{array}$ \\
\hline
\end{tabular}

\section{LITERATURE REVIEW}

Working capital is a term frequently used in the corporate world and is the most significant definition of the lifeline of every corporation. Working capital is calculated by subtracting current assets from current liabilities and 
refers to cash made available for a company's daily operation. In banks' everyday activities, efficient working capital management (WCM) arises because too much or too little working capital can create a serious problems in both the short and long terms (Onwumere, Ibe, \& Ugbam, 2012). Excessive working capital involves the retention of significant cash reserves that are not used for productivity and profitability. Instead, funds that are meant to be invested are left idle and the bank does not receive any interest. Too little working capital will do greater shortterm harm to a bank's results; this is because more of the liquidity has been spent for profit. As such, the bank will not be able to satisfy the regular withdrawal demands from its clients. This will spark distrust from clients and cause a bank run that will have a ripple effect of bank distress.

The primary financial goal is to maximize shareholders' wealth, which ensures excellent financial performance. Large-capital banks will grow as they expend surplus cash on productive undertakings and attractive acquisition prospects while retaining ample liquidity. Banks with comparatively low capital ratios, on the other hand, would have a very passive investment appetite since they need to maintain liquidity adequately and not actively invest finite idle funds in long-term ventures to reduce liquidity risk (Susan \& Nasieku, 2016). Deposit money banks with comparatively large resources have the viability factor. They are seen as a haven for bringing money in by the general public, prospective buyers and depositors, and this attractiveness generates more patronage and a bigger market (Agbeja, Adelakun, \& Olufemi, 2015). Deposit money banks must maintain appropriate amounts of liquidity at all times as a company that is supposed to continue operations in perpetuity. Sufficient capital makes idle resources available for the bank to use to fund prospective businesses' credit needs that represent a significant income stream for banks, thereby enhancing their earnings and financial performance. In finance, the capital adequacy ratio reveals the amount of capital that serves as an indicator or gauge that shows the level of soundness and security of banks and other deposit money institutions; this is because capital is a buffer for enduring shocks and heavy investment losses (Posner, 2014).

Adagye (2015) investigated the nexus between WCM and the profitability of DMBs registered on the Nigerian Stock Exchange in 2013. This research study employed returns on equity (ROE) and returns on assets (ROA) as explained variables for profitability. At the same time, cash reserve ratio (CRR), pre-taxation profit to current liabilities (PCL), operating cash flow to current liabilities (OCL) and cash balance to total liabilities (CTL) are substitutes for working capital and as well explanatory variables. The study revealed that a significant and direct relationship exists between WCM and the profitability of the Nigerian DMBs. The result showed that all the components of WCM directly influenced the two profitability substitutes. Accordingly, the study proposes that DMBs should ensure that suitable WCM is mandatory to achieve their profitability-boosting target. Examining the Yahaya \& Bala (2015) study, which is centered on working capital management and the financial performance of deposit money banks from 2007 to 2013, the ordinary least squares (OLS) regression analysis was employed and they found out that liquidity has a substantial impact on the profitability of deposit money banks.

Furthermore, firm size was tested and the results concluded that it did not significantly influence a bank's performance. Mandiefe (2016) examined whether working capital management had any effect on the profitability of Afriland First Bank and it was concluded that it did influence the profitability. Data from 2002 to 2013 were retrieved from the bank's financial position statement and analyzed using the ordinary least squares method. Umoru \& Osemwegie (2016) focused on the significance of capital adequacy on banks' financial performance from 2007 to 2015. The methodology used was the GLS estimation technique and the results concluded that the selected banks could weather the economic downturn storm during this period due to capital adequacy. Therefore, capital adequacy was found to be essential in sustaining good bank performance.

In their trading operations and functions, deposit money banks may decide to retain lower capital levels, but this does not outweigh the risks involved in credit administration (Cheruiyot, 2016). As a part of this, regulatory agencies have acted to ensure that banks maintain the necessary amount of capital by passing legislation. Regulatory controls are essential to ensure the financial system's soundness and integrity to minimize risk and 
increase consumer trust in the system. This is because banks play a crucial role in a country's economic development; hence, government agencies' interference through regulation is warranted. The collapse of the banking system means a collapse of a country's economy because banks are the largest money market producers and finance sources (Wangui, 2012). In principle, the amount of money held by a bank is influenced by financial success. Adequate capital levels allow a bank to diversify its portfolio and extend its reach, thus reducing the probability of risk occurrence and ensuring stability (Cheruiyot, 2016). Finally, adequate capital levels form the benchmark for building confidence and trust among stakeholders. The banking sector is considered as the lifeblood of an economy as it helps in lubricating the payment and settlement activities within an economy as most deposit money banks prefer financing the top sectors within an economy to help improve their working capital position (Osuma, Babajide, Ikpefan, Nwuba, \& Jegede, 2019).

Simon-Oke (2019) examined the nexus between working capital management and small and medium enterprise (SME) performance in Akure, Nigeria. The study adopted a descriptive survey with the primary data collection source through a well-structured questionnaire, while both descriptive and inferential statistics were used to analyze data. The study discovered that a significant and direct relationship exists between working capital and the performance of SMEs. Bank loans, loans from family members and friends, and personal savings were found to be substantial sources of financing working capital. The study further concluded that effective working capital management ensures that SMEs have enough funds for the business's day-to-day running.

This suggests consideration of other financing sources, such as cooperative societies, for the optimum performance needed by SMEs to annex the potentials for sustainable growth and development. Osuji \& Agbada (2020) studied the requirements for productive profitability in the Nigerian banking sector. Specifically, working capital management (WCM) key variables, such as short-term investments, client's funds, and accounts receivable and payable were employed as substitutes. Data were collated using questionnaires and analyzed with the use of the Pearson product-moment correlation coefficient. Although the values of ' $r$ ' revealed signs affirming a direct relation, the power of relationship is on the mean. The importance of $\left(\mathrm{r}^{2}\right)$ verified this; specifically, the variable 'funds given to clients', which was minimal at 0.2229 , indicated that the variable described only a $22.29 \%$ variation in profitability. The findings proposed that WCM factors haven't generated adequate cash flows that could maximize income. Therefore, the study recommended that WCM variables should be effectively monitored to avoid cases that lead to loss of funds.

O’Neil \& Wingaroja (2018) noted that effective WCM guarantees liquidity availability for all ongoing business operations and profit achievement-creating methods in the organization. Maverick (2019) reiterated that effective WCM requires many activities to be coordinated, but the essential and fundamental areas include handling shortterm investments, handling funds to clients, and operating accounts receivable and payable.

\subsection{The Tradeoff Between Liquidity EPProfitability}

Liquidity is called a flow principle in economics since a company can fulfill its short-term liabilities, and this is calculated over a period of time. To settle loans and meet internal and external commitments, a company can also turn investments into currency. Liquidity plays a significant role in a bank's activities and a lack of liquidity will create a standard for bank failure. However, profitability refers to a company's capacity to generate income or revenue more significantly than income-generating expenses or expenditure. Profitability is also a company's ability to create a return on investment effectively from the properties it owns. The assets and liabilities of a bank play a central role in balancing risk and the production of liquidity (Nishanthini \& Meerajancy, 2015). Resources that are readily convertible to cash appear to play little or no part. A good example is cash, as deposit money banks will do everything within their means to ensure their reserves of liquid assets are held at a fair reduced rate (Elliott, 2014).

A group of 29 firms in Saudi Arabia was studied by Eljelly (2004). The findings from their study showed an inverse relationship between profitability and liquidity. The facts discussed here reiterated the need for a working 
equilibrium of liability and profitability. The reasoning is that for every company in question, policy decisions are taken on working capital that improve profitability and aim to reduce liquidity, and vice versa. Illiquidity generally means decreased benefits, limited investment options, uncertainty in ownership, bad debt, bankruptcy, and even insolvency. Adagye (2015) argued that there is an inverse association between liquidity and profitability. Suppose the operating capital of a company increases proportionately to its revenue. In that case, the effect will be such that profitability and risk will decline, while the liquidity of the business in question will increase. The company then decides to follow a strategy of maintaining liquidity and seeks to boost its liquidity position; a fresh rise in working capital will be asked for. Suppose the company is risk-tolerant and strives for a more considerable improvement in its return on investment. In that case, the decision to minimize working capital with revenue will have to be made. Based on the company's policy judgment on either liquidity or profitability at the time, the conditions for working capital should then be calculated accordingly.

\subsection{Significance of Working Capital Management}

Bala \& Yahaya (2015) noted that working capital management (WCM) aims to sustain an equilibrium between liquidity and profitability while handling a company's day-to-day activity. Joshi (2013) inferred that WCM is a significant aspect of financial management. It is the core of any corporate enterprise because no business can operate smoothly without proper management of its working capital. It directly influences the viability and liquidity of companies regardless of their size.

The need for stable and effective control of working capital cannot be emphasized enough in an ever-expanding economic environment. Working capital is a deliberate routine of continually retaining surplus liquid assets over current liabilities (Osuma et al., 2018), and is the basis on which the treasury administration rests. Working capital management controls existing assets' adequacy and controls current liabilities' risk threat rate (Umoren \& Udo, 2015). If a bank is negligent in handling working resources, it will likely become bankrupt and not be able to meet its commitments to stakeholders. Besides, a bank's current ratio should be higher than one to ensure that existing assets will catch up on current liabilities as debt occurs and even when financial commitments have to be fulfilled. The benefits are that the bank would have a higher return on invested capital, enhanced solvency ratios, better performance and liquidity, the capacity to survive shocks or crises in the economy and satisfy consumer demands at peak times. There is a time gap between unsold items and cash collection for such goods for trade organizations. This also enhances the need for careful control of working capital to ensure that there is no financial restriction on the part of the company. Other options include investing in marketable short-term securities to raise net reserves and maintain a stable working capital position.

Osuji \& Agbada (2020) further reiterated that WCM is of immense significance in the banking sector. It is relied upon by deposit money banks (DMBs) to maintain the goal of generating profit liquidity. DMBs are the primary financial institutions that play a critical position in economic development and saving and investment. They are also sources of commerce and business funding and play a fundamental role in the nation's financial and commercial life. They also have an incentive to accumulate savings and earned deposits to grow individual businesses, trade, and corporate organizations. The above has demonstrated that working capital is not a problem that can be conveniently ignored, but more accurate, proactive and cautious preparation should be included in developing every company's working capital strategy as it will significantly affect every organization.

\subsection{Liquid Asset Theory}

This study focuses on the liquid assets theory, which focuses on the statement of financial position's asset section and maintains that deposit money banks must preserve substantial reserves in liquid assets to deal with emergencies. In other words, extremely marketable securities should be kept to ensure quick conversion to cash to 
satisfy the demand of withdrawals. Banks need liquid assets to mitigate the risks inherent in the use of short-term liabilities to fund long-term assets (Altaee \& Adam, 2014).

\section{METHODOLOGY}

3.1. Population and Sample of the Study

A total sample of six of the 23 DMBs in Nigeria were chosen for data collection in this report. This includes two old generation banks (banks founded in Nigeria before 1989), including First Bank and United Bank for Africa, and four new generation banks (banks established in Nigeria after 1989), including Zenith Bank, Access Bank, Sterling Bank and Guarantee Trust Bank. A random sampling technique was used to pick six deposit money banks, as seen in Table 2.

Table 2. Sample of the study.

\begin{tabular}{l|l|c|l}
\hline S/N & Banks (PLC) & Year Established & Classification \\
\hline 1. & First Bank PLC. & $(1894)$ & Old generation bank \\
\hline 2. & United Bank for Africa PLC. & $(1948)$ & Old generation bank \\
\hline 3. & Access Bank PLC. & $(1989)$ & New generation bank \\
\hline 4. & Guaranty Trust Bank PLC. & $(1990)$ & New generation bank \\
\hline 5. & Zenith Bank PLC. & $(1990)$ & New generation bank \\
\hline 6. & Sterling Bank PLC. & $(2006)$ & New generation bank \\
\hline
\end{tabular}

\subsection{Model Specification}

We reduced the theories to mathematical claims for an empirical context to validate this study's hypothesis. Even so, when defining mathematical models, the mathematical representations of the functional form represented by our hypotheses are expressed as follows:

$$
R O A_{t}=f\left(C A R_{t-1}, L R_{t-1}, L D R_{t-1}\right)
$$

Where:

$R O A_{t-1}=$ return on assets $(\mathrm{ROA})$ of banks with respect to lag.

$C A R_{t-1}=$ capital adequacy ratio $(\mathrm{CAR})$ of banks with respect to lag.

$L R_{t-l}=$ liquidity ratio $(\mathrm{LR})$ of banks with respect to lag.

$L D R_{t-1}=$ loan-to-deposit ratio (LDR) of banks with respect to lag.

The expression in Equation 1 shows that return on assets (ROA) is a function of many variables such as CAR, LR and LDR, which are independent. ROA is a capital adequacy ratio (CAR) mechanism that aims to decide to what degree the minimum capital needed to be retained by the bank will impact the return on profitability-measuring properties. As a liquidity ratio (LR) function, ROA attempts to assess the degree to which the amount of highly liquid reserves retained by banks influences their profitability as determined by asset return. As a feature of the loan to deposit ratio (LDR), ROA seeks to determine to what degree the granting of loans and advances against deposits retained can impact banks' profitability as determined by their return on assets.

\section{DATA ANALYSIS \& RESULT INTERPRETATION}

This section includes the pre-estimation techniques to determine the appropriateness of the model variables. Table 3 which is the correlation matrix table, and Table 4, which is the variance inflation factor table, show the results from the test for the incidence of multicollinearity in the model and the panel least squares regression estimates, respectively; Table 6 shows the robustness test.

The model and a priori expectations are stated in Equations 2 and 3:

Research model: $R O A_{t}=\alpha_{o}+\alpha_{t} C A R_{t}+\alpha_{2} L R_{t}+\alpha_{s} L D R_{t}+\mu_{t}$

A priori: $\alpha_{1}, \alpha_{2}, \alpha 3>0,<0$ 
This means that all things being equal, return on assets would be positively impacted by capital adequacy ratio, liquidity ratio and loan-to-deposit ratio. Therefore, positive coefficients should be expected for CAR, LR and LDR.

Table 3. Correlation Matrix.

\begin{tabular}{c|c|c|c|c}
\hline Variables & ROA & LR & LDR & CAR \\
\hline ROA & 1.000000 & & & \\
\hline LR & 0.283467 & 1.000000 & -0.651746 & 0.360594 \\
\hline LDR & 0.375639 & -0.651746 & 1.000000 & -0.098411 \\
\hline CAR & 0.305788 & 0.360594 & -0.098411 & 1.000000 \\
\hline
\end{tabular}

All independent variables (LR, LDR and CAR) are positively associated with the dependent variable from Table 3. Simultaneously, there is a negative relationship of -0.65 between the liquidity ratio and the loan-to-deposit ratio. In contrast, a positive association of 0.36 between the liquidity and capital adequacy ratios was established. Also, there is a negative relationship of -0.098 between LDR and CAR, but none of the variables' coefficients are greater than 0.8 , indicating that multicollinearity is not present.

Table 4. Variance Inflation Factor.

\begin{tabular}{|c|c|c|c|}
\hline & Coefficient & Uncentered & Centered \\
\hline Variable & Variance & VIF & VIF \\
\hline $\mathrm{C}$ & 71300 & 1.48 & NA \\
\hline LR & 57 & 1.06 & 3.5674244 \\
\hline LDR & 3470 & 1.30 & 2.4627241 \\
\hline CAR & 528000000 & 1.08 & 1.0878759 \\
\hline
\end{tabular}

Just as in Akinde, Peter, \& Ikpefan (2019) and Ehikioya, Omankhanlen E, Osuma, \& Inua (2020), the variance inflation factor was to further confirm the authenticity of the results in Table 3. From the results, it can be deduced that there is no multicollinearity incidence as none of the values is above five.

Table 5. Pooled Regression.

\begin{tabular}{l|c|c|c|c}
\hline \multicolumn{1}{l}{ Dependent variable: ROA } & & \\
\hline Variable & Coefficient & Std. Error & t-Statistic & Prob. \\
\hline$C$ & -0.046648 & 0.019242 & -2.424233 & 0.0195 \\
\hline$L D R$ & 0.048127 & 0.015648 & 3.075703 & 0.0036 \\
\hline$L R$ & 0.031797 & 0.023959 & 1.327119 & 0.0191 \\
\hline$C A R$ & 0.106260 & 0.037747 & 2.815066 & 0.0073 \\
\hline R-squared & 0.529602 & Mean dependent var. & 0.022535 \\
\hline Adjusted R-squared & 0.283893 & S.D. dependent var. & 0.013554 \\
\hline S.E. of regression & 0.011470 & Akaike info. criterion & -6.018481 \\
\hline Sum squared resid. & 0.005789 & Schwarz info. criterion & -5.862548 \\
\hline Log likelihood & 148.4435 & Hannan-Quinn criterion & -5.959554 \\
\hline F-statistic & 7.210870 & Durbin-Watson stat. & 0.983260 \\
\hline Prob (F-statistic) & 0.000487 & \multicolumn{4}{|}{} \\
\hline
\end{tabular}

\section{INTERPRETATION}

In terms of the signs of the coefficient, the approximate regression result provided in Table 5 is satisfactory as it conforms to the a priori theoretical assumption of this analysis.

This assumes that the loan-to-deposit ratio, the liquidity ratio and the capital adequacy ratio will positively affect asset return. Table 5 shows that this contributes to a 0.048 unit rise in returns on investment with every oneunit increase in the loan-to-deposit ratio. Also, a proportional unit increase of 0.032 in return on investment is 
required for every one-unit increase in the liquidity ratio. Table 5 also indicates that a unit increase in the capital adequacy ratio would increase investment return by 0.11 units. LDR and CAR, from the t-statistic column, are statistically significant when their respective coefficients of 3.076 and 2.815 are more significant than 2 . On the other hand, the liquidity ratio is statistically negligible, as its coefficient of 1.327 is less than 2 .

In comparison, the probability value of the LDR and CAR coefficient result is less than 0.05 (i.e., < 5\%), meaning that both are statistically important. However, the LR is statistically negligible since its coefficient of 0.1913 is higher than 0.05. The R-squared with a value of 0.5296, which is the coefficient of determination, is positive and reasonably high. This value shows that the independent variable will explain $53 \%$ of the variance in the dependent variable. In comparison, the remaining 43\% cannot be clarified and are termed as outliers along the regression axis. This suggests that much of the data would not converge along the regression line as the data is plotted on a graph, making the existence of outliers visible. At the $5 \%$ mark, the average panel data regression is statistically significant. This statement is based on an F-statistic with a value of 7.21 and a chance of less than 0.05 (F-statistic of 0.000487). This implies that the independent variables are jointly significant. T-statistics, R-squared, and F-statistics are accurate, and it is appropriate to use the whole ordinary least squares regression.

From Table 5, it can be deduced that the loan-to-deposit ratio $(L D R)$ has a probability value of 0.0036 , which is statistically significant at $5 \%$. From the p-value, it can be inferred that the alternative hypothesis $\left(\mathrm{H}_{1}\right)$ would be accepted, while the null hypothesis $\left(\mathrm{H}_{0}\right)$ is rejected. The alternative hypothesis states that liquidity has a significant effect on working capital management. This translates to a one percent increase in a bank's liquidity leads to a rise in profitability and, conversely, every decrease in a bank's liquidity results in a decline in profitability. Table 5 shows the panel least squares regression value for capital adequacy ratio $(C A R)$ and return on assets. The table shows the $C A R$ coefficient as 0.106 . This figure is positive and has a probability value of 0.0073 , which is well below the 0.05 level. The coefficient value also indicates that a unit change in capital adequacy ratio, profitability measured by return on assets increases by 0.106 units. With the above indices, the null hypothesis is rejected and the alternative hypothesis is accepted, indicating a significant relationship between capital adequacy and productivity. The liquidity ratio $(L R)$ of 0.031 shows that a change in $L R$ positively affects profitability. A probability value of 0.0191 shows statistical insignificance at the $5 \%$ level and an overall F-statistic value of 0.000487. The table shows that a one-unit increase in $L R$ leads to a 0.048 unit increase in profitability measured by return on assets. The null hypothesis is rejected and the alternative hypothesis that deposit money banks' profitability is significantly affected by loans and advances is accepted.

Table 6. Robustness Test.

\begin{tabular}{|c|c|c|c|c|c|}
\hline ROE MODEL & & & INC_PAT MODEL & Prob. & \\
\hline \multirow{3}{*}{$\begin{array}{l}\text { Heteroskedasticity Test: } \\
\text { ARCH }\end{array}$} & & Prob. & \multirow{3}{*}{$\begin{array}{l}\text { Breusch-Godfrey } \\
\text { Correlation LM Test }\end{array}$} & & Prob. \\
\hline & Prob. $\mathrm{F}(1,36)$ & 0.7219 & & Prob. F(2,50) & 0.9680 \\
\hline & $\begin{array}{ll}\text { Prob. Chi- } \\
\text { Square(1) }\end{array}$ & 0.8043 & & $\begin{array}{ll}\text { Prob. Chi- } \\
\text { Square(2) }\end{array}$ & 0.7643 \\
\hline
\end{tabular}

Table 6 presents both the serial correlation test and heteroscedasticity test. Their p-values are greater than $5 \%$ (i.e., $\mathrm{p}>0.05$ ), which means that the null hypothesis $\left(\mathrm{H}_{0}\right)$ of homoscedasticity is assumed. At the same time, the alternative hypothesis $\left(\mathrm{H}_{1}\right)$ of heteroscedasticity is rejected. The serial correlation and the autoregressive conditional heteroscedasticity $(\mathrm{ARCH})$ show no problem with the model specification.

\section{CONCLUSION}

A bank could not fund regular operations, such as meeting consumer withdrawal demands, through excess unguarded investment and large short-term loans, a lack of which would cause panic and, consequently, a bank run. This would leave the bank in more financial trouble and would pose a structural danger to the financial sector. On 
the other hand, if capital is left idle and not wisely spent, the bank would surpass its profitability goal. It can be understood from the above points that a tradeoff is taking place. Banks have to objectively weigh their choices and make decisions to ensure that they can repay loan commitments and still attain their profitability target.

However, the conclusions from the perspectives of other scholars were compatible with the results of this analysis. The philosophy of liquid assets believes that banks must retain vast volumes of liquid assets to guard against future demand or unexpected conditions and fund working capital activities. The fundamental principle here is that bank liquidity will contribute to an improved capacity to satisfy consumer demands and, in the long run, improve profitability given the assumption that the bank will wisely invest its idle reserves in delivering good returns. On the other hand, if a bank retains adequate liquidity and makes poor investment decisions, income and, inevitably, liquidity would be wasted because it does not get enough dividends to shore up liquidity demands and shortfalls. Banks must ensure optimum overall capital, which should be above the specified minimum regulatory capital. This would facilitate a sufficiently sound financial system that can sustain and withstand acceptable levels of losses, not requiring banks to stop its Tier 1 capital trading. Furthermore, it should retain adequate resources to guarantee that it can absorb losses; this is defined as Tier 2. The analysis shows that the DMBs operate at an optimum capital level where overtrading (undercapitalization) and undertrading (overcapitalization) are avoided.

This study offers the following recommendations:

- To aid banks in handling their liquidity ratios effectively, direct policies should be implemented to ensure that high-volume cash trades and the concentration of cash holding power in the Nigerian economy are dramatically minimized. When these policies are achieved, the banks can utilize liquidity of a sufficient level to satisfy commitments and lending purposes for a short period.

- There is a need for the Central Bank of Nigeria to update the required capital adequacy limits for various bank classifications to significantly higher limits. This is to ensure that more financially stable banks can handle fair levels of losses without causing the banks to stop trading.

- Better supervision (i.e., adequate checks and balances) should be considered to ensure higher earnings on income from loans and advances to stop the emergence of bad debts that substantially affect the banks' profitability.

- Since the bulk of the earnings of a bank's interest is from the loans and advance accounts, there is a need for more commitment to the regular training and retraining of workers employed in the credit department to ensure that they are adequately prepared to manage all loan assessment procedures.

Funding: The authors extend their sincere appreciation to Covenant University for sponsoring this research.

Competing Interests: The authors declare that they have no competing interests.

Acknowledgement: All authors contributed equally to the conception and design of the study.

\section{REFERENCES}

Adagye, I. (2015). Effective working capital management and the profitability of quoted banks in Nigeria. European Journal of Accounting Auditing and Finance Research, 3(2), 97-107.

Agbeja, O., Adelakun, O., \& Olufemi, F. (2015). Capital adequacy ratio and bank profitability in Nigeria: A linear approach. International Journal of Novel Research in Marketing Management and Economics, 2(3), 91-99.

Akinde, M. A., Peter, E., \& Ikpefan, O. A. (2019). Growth versus value investing: A case of Nigerian Stock Market. Investment Management and Financial Innovations(16, Iss. 1), 30-45.Available at: https://doi.org/10.21511/imfi.16(1).2019.03.

Altaee, H. H. A., \& Adam, M. H. M. (2014). An empirical evaluation of demand for liquid financial. European Journal of Accounting Auditing and Finance Research, 2(6), 56-68.

Bala, H., \& Yahaya, A. (2015). Working capital management and financial performance of deposit money banks in Nigeria. Research Journal of Finance and Accounting, 6(16), 57-71. 
Cheruiyot, R. K. (2016). Effect of asset quality on profitability of commercial banks in Kenya (pp. 1-47). Kenya: Business School, University of Nairobi.

Ehikioya, B. I., Omankhanlen E, A., Osuma, G., O., \& Inua, O., I. (2020). Dynamic relations between public external debt and economic growth in African countries: A curse or blessing? Journal of Open Innovation Technology Market and Complexity, 6(88), 1-16.Available at: 10.3390/joitmc6030088.

Eljelly, A. M. A. (2004). Liquidity - profitability tradeoff: An empirical investigation in an emerging market. International Journal of Commerce and Management, 14(2), 48-61.

Elliott, D. J. (2014). Bank liquidity requirements: An introduction and overview. Washington, USA: The Brookings Institution.

Joshi, R. (2013). Working capital management of commercial banks in Nepal: Being an M.sc. Thesis submitted to faculty of management Tribhuvan University, Shankar Dev. Campus, Kathmadu.

Leeson, J. (2017). Concept of working capital. International Journal of Commerce, Business and Management, 5(2), 3-9.

Mandiefe, S. P. (2016). How working capital affects the profitability of commercial banks: Case of Afriland Cameroon. Arabian Journal of Business and Management Revierw, 6(46), 1-9.

Maverick, J. (2019). What Is working capital management? Retrieved from: https://www.investopedia.com/ask/answers/041015/what-are-components-associated-working-capitalmanagement.asp.

Nishanthini, A., \& Meerajancy, J. (2015). Trade-off between liquidity and profitability: A comparative study between State Banks and private Banks in Sri Lanka. Journal of Research on Humanities and Social Sciences, 5(7), 78-85.

O'Neil, S., \& Wingaroja, G. (2018). A study of small firm exports, policies and support institutions in mauritius. Export and Industrial Development Division. United Kingdom: Commonwealt Secretariat.

Olabamiji, O., \& Michael, O. (2018). Credit management practices and bank performance: Evidence from $\quad$ First Bank. South Asian Journal of Social Studies and Economics $\quad 1(1), \quad 1-10$. Available at: https://doi.org/10.9734/sajsse/2018/v1i125772.

Oluwakayode, A. M. (2017). Causes and effects of banking distress in Nigeria banking industry. International Academic Journal of Accounting and Financial Management, 4(1), 100-105.

Oluwatoyin, O. R. (2017). The effect of working capital management on profitability: A case of listed manufacturing. Research Journal of Finance and Accounting, 14(2), 336-346.

Onwumere, J., Ibe, I. G., \& Ugbam, O. (2012). The impact of working capital management on profitability of Nigerian firms: A preliminary investigation. European Journal of Business and Management, 4(15), 192-201.

Osuji, C. C., \& Agbada, O. A. (2020). Imperatives of effective working capital management and profitability in the banking industry in Nigeria. International Journal of Financial Research, $11(2), 229-242$.

Osuma, G., O., Ailemen, I., Osabohien, R., Chisom, N., \& Pascal, N. (2018). Working capital management and bank performance: empirical research of ten deposit money banks in Nigeria. Banks and Bank Systems, 13(2), 49-61.

Osuma, G. O., Babajide, A. A., Ikpefan, O. A., Nwuba, E., B., \& Jegede, P., W. (2019). Effects of global decline in oil price on the financial performance of selected deposit money banks in Nigeria. International Journal of Energy Economics and Policy, 9(3), 187-195.Available at: https://doi.org/10.32479/ijeep.7514.

Posner, E. A. (2014). How do bank regulators determine capital adequacy requirements? The University of Chicago Law Review, 82(4), 1853-1895.

Simon-Oke, O. O. (2019). Working capital management -performance relationship: A study of smalland medium enterprises in Akure, Nigeria. International Journal of Commerce and Management Studies, 4(4), 1-11.

Susan, J. K., \& Nasieku, T. (2016). Effect of capital on the financial performance of commercial banks in Kenya. Asian Journal of Business and Management, 04(05), 22 1-238.

Umoren, A., \& Udo, E. (2015). Working capital management and the performance of selected deposit money banks in Nigeria. British Journal of Economics, Management \& Trade, 7(1), 23-31. 
Asian Economic and Financial Review, 2021, 11(6): 418-428

Umoru, D., \& Osemwegie, J. O. (2016). Capital adequacy and financial performance of banks in Nigeria: Empirical evidence based on the fgls estimator. European Scientific Journal, 12(25), 295-305.Available at: https://doi.org/10.19044/esj.2016.v12n25p295.

Wangui, W. M. (2012). The effect of capital adequacy requirements on-. International Research Journal of Finance and Economics, $66(66), 133-146$.

Yahaya, A., \& Bala, H. (2015). Working capital management and financial performance of deposit money banks. Research Journal of Finance and Accounting, 6(16), 57-71.

Views and opinions expressed in this article are the views and opinions of the author(s), Asian Economic and Financial Review shall not be responsible or answerable for any loss, damage or liability etc. caused in relation to/arising out of the use of the content. 